Article

\title{
Exploring the Proactivity Levels and Drivers of Environmental Strategies Adopted by Vietnamese Seafood Export Processing Firms: A Qualitative Approach
}

\author{
Binh Do ${ }^{1, *}$, Uyen Nguyen ${ }^{1}$, Ninh Nguyen ${ }^{2}$ and Lester W. Johnson ${ }^{3}$ \\ 1 Faculty of Business Administration, Thuongmai University, 79 Ho Tung Mau Road, Hanoi 100000, Vietnam \\ 2 Department of Entrepreneurship, Innovation and Marketing, La Trobe Business School, La Trobe University, \\ Bundoora, Victoria 3086, Australia \\ 3 Department of Management and Marketing, Swinburne Business School, Swinburne University of \\ Technology, Hawthorn, Victoria 3122, Australia \\ * Correspondence: binhdt@tmu.edu.vn; Tel.: +84-989-956-957
}

Received: 27 June 2019; Accepted: 18 July 2019; Published: 22 July 2019

check for updates

\begin{abstract}
Export processing firms from emerging markets often need to adjust their export strategies towards environmentally friendly directions to address strict regulatory requirements and increasingly environmental concerns among the public and consumers in advanced countries. This study aims to explore and evaluate different proactivity levels and drivers of environmental strategies (ESs) adopted by Vietnamese seafood export processing firms. Data was obtained from two sources: Public archival data of 32 listed firms, and semi-structured interviews with 44 managers from seafood export processing firms. Content analysis revealed that reactive ESs were adopted the most by Vietnamese seafood export processing firms, followed by opportunistic ESs, focused ESs and proactive ES, respectively. The findings also demonstrated that both internal factors and external factors in home and host countries motivate the firms to pursue different ESs. This study sheds light on unexplored characteristics and drivers of ESs in Vietnam and it assists key stakeholders including export processing firms and policymakers in the adoption, development and promotion of ESs.
\end{abstract}

Keywords: environmental strategy; proactivity levels; drivers of environmental strategy; seafood export processing firms; Vietnam

\section{Introduction}

The excess of nine billion people in world population has put human societies in enormous challenges for food and livelihoods, while witnessing some environmental destruction. The 2030 Agenda of the United Nations for Sustainable Development aims to shift the world towards sustainable development with 17 Sustainable Development Goals (SDGs), which include responsible consumption and production [1]. This Agenda has called for increasing scrutiny from governments, NGOs, support groups and other stakeholders and put heavy environmental pressure on firms in general and on export firms in particular [2-6]. Amongst them, export companies from emerging countries like Vietnam face more challenges since they are confronted with higher ecologically conscious consumers, regulatory compliance and environmental public concern in advanced countries. These challenges in turn put the export companies under higher pressure of adjusting their export strategies toward more environmentally friendly directions. Shifting business strategies to eco-friendly strategies is not only the way to help export companies to access the global market, but also helps them to exploit green-related opportunities to achieve the entire set of SDGs [1,2,7]. 
Increased environmental pressure has driven the new line of research, concentrating on the so-called environmental, eco-friendly, environmentally friendly or green strategy $[4,6,8]$. Thus far, there are three major streams of studies on environmental strategies (ESs): (1) Drivers and barriers of the adoption of ESs; (2) integrated models linking antecedents to consequences of ESs and (3) the change in corporate ESs or the level of ES proactivity [6,9-12]. It should be mentioned that research on the first two streams have selected participating companies from different industries [6] that have different regulatory context rather than a uniform set of environmental policies for a single industry. Thus, it is necessary for future research to put emphasis on a specific industry to thoroughly understand the drivers and consequences of ESs within the same regulatory context. This was also supported by the argument on whether each industry would require different treatment [13]. In addition, it is observed that the third research stream on changes in corporate ESs remains limited, insufficiently revealing the holistic picture of environmental proactivity levels adopted by firms. Notably, all the three research streams on ESs have concentrated on the domestic context rather than international context $[6,8,14]$. There is also a lack of empirical evidence on the drivers of ESs from emerging economies $[6,8,15]$. Drivers of firms' ESs in emerging countries could be significantly different from those found in Western countries [15]. Therefore, exploratory research on proactivity levels and drivers of ESs could be worthy to give a holistic understanding of ESs in the context of emerging economies [15].

In light of the aforementioned gaps, this study evaluates different proactivity levels of ESs adopted by firms in a specific industry in the context of an emerging country, as well as explores prominent internal and external drivers of ESs in both home and host countries. Specifically, it aims to address two main questions: (1) What are the proactivity levels of ESs of Vietnamese seafood export processing firms; and (2) what are the driving factors that stimulate these firms to adopt ESs? Answering these two unfulfilled questions will contribute to the literature associated with ESs as well as provide relevant information for key stakeholders (e.g., processing firms, suppliers, policymakers and non-governmental organizations) that are involved in the adoption, development and promotion of ESs in Vietnam. Given the low level of environmental awareness in Vietnam and the complexity of drivers of firms' ESs, this study suggests two propositions: (1) The majority of Vietnamese seafood export processing firms adopt lower proactivity levels of ESs; and (2) both internal and external factors play vital roles in stimulating these firms to adopt ESs. As the present study is exploratory in nature, a qualitative method is utilized as it provides rich information about undetermined drivers of firms' ESs in emerging countries [16].

Another contribution of this study concerns its focused context, Vietnamese seafood exporting firms. Remarkably, aquaculture and fisheries are directly involving to many SDGs; and seafood trade worldwide that is valued at USD 362 billion in 2016 is an important source to achieve SDGs [1]. Among the World's top four seafood exporters from 2016 and recently exporting to 120 countries and territories [1], Vietnam has become an important producer of seafood. However, the environmental sustainability problems confronting the accelerated growth and intensive farming of fisheries and shrimp in Vietnam are enormous [17]. In recent years, Vietnam seafood shipments have been warned by the authorities of the EU, US and Japan - key export markets. Despite the number of shipments being warned having fallen sharply from 128 in 2016 to 98 in 2018 [18], it still is at a high level, which has a bad impact on Vietnamese seafood's image and prestige on the global market. Therefore, shifting business strategies to ESs is a call for Vietnam seafood export processing firms towards sustainability development.

The remainder of this paper is organized as follows. The next section presents a review of the literature pertaining to ESs, proactivity levels of ESs as well as internal and external drivers of ESs in accordance with the institutional theory and resource based perspectives. Thereafter, the qualitative research methods are explained, which is followed by the research results. After that, the findings and their implications are discussed. Finally, concluding remarks and future research directions are presented. 


\section{Literature Review}

\subsection{ES and Proactivity Levels of ESs}

According to Das et al. [19] (pp. 1-2), "corporate ES represents a firm's strategy concerning the sustainable business-natural environment". Accordingly, a firm that pursues this strategy will put effort into limiting the negative effect on the environment from producing and using their product or services to meet the requirements from different stakeholders such as governments, consumers, communities and many other related individuals and groups [2,19-21]. Besides this social corporate responsibility (CSR) objective, the utilization of a sound ES was also demonstrated to bringing several benefits for improvement of a competitive advantage and organizational performance [21,22]. Hence, enhancement of ESs adoption is not only a response to the environment requirement from stakeholders but it is also the motivation of the firm in strengthening their competitive advantage and performance indicators [12,22-25].

Oliver [26] argues that a firm's strategic response to environmental problems depends on its willingness and ability to conform the environmental issues from its context, which is presented as managerial recognition [2]. Several previous studies have also indicated that the ESs of firms also varied with the managerial perception of environment issues [27-29], even in the same industry [2,6,12]. An organization is part of a network among multiple stakeholders, therefore, it has to respond to the demands as well as pressures from stakeholders [30]. Accordingly, managerial perceptions of environmental needs and pressures that can be considered as opportunities and threats derived from the external environment and organizational context shape decision-making as well as the level of ES adoption [2,6,12,31]. Therefore, exploring the drivers of ESs including institutional factors and the firm's internal characteristics through the managerial perception is a meaningful and prominent approach that is raising more concerns in recent literature.

Lee and Rhee [12] (p. 197) assert that the differences in leaders' recognition of environmental issues and firm's choice of environmental practices result in distinctive ES types. They therefore refer to ES as "a firm's selection of the width and depth of environmental-friendly practices and activities". The ES's width was clarified as the range of environmental issues that are taken into account and the depth of corporate ES is the extent to which the firm adopted responses to these environmental areas. The firm can choose various areas of concern such as product, organization and systems, process, supply chain and recovery, and the external relationship [12]. The depth of ES is measured by the degree of the effort as well as its resources invested into the environmental management and areas that the firm has chosen. As such, the depth of ES reflects how deeply the firm deals with environmental issues to meet the needs of different stakeholders [12].

To clarify these different levels of ES that represent different levels of depth and width, prior studies suggested the variability of ESs ranging from reactivity to proactivity [32] or from reactive ES, focused ES, opportunistic ES to proactive ES [12] subject to managerial perception about the environmental issues [2,31]. Companies with the reactive ES seem to ignore the environmental issues. This type of ES represents a low level of both chosen decision areas and environmental responsiveness. Notably, reactive ES was found to be related to worse environmental performance in a study performed by Kim [33]. Companies that adopt focused ES primarily concentrate on compliance with regulations and pollution control. These firms usually implement so-called end-of-pipe solutions that are corrective and perform activities that minimize risk, liabilities and costs [12,34]. In addition, focused strategic firms demonstrate concerns on environmental issues in limited decision areas. Adoption of opportunistic strategy shows that firms consider all environmental decision areas, however at the same time they do not put whole effort to gain the more advanced level of environmental management in all environmental decision areas. The opportunistic ESs undertake a higher than intermediate level of environmental activities in all decision areas such as supply chain, product recovery and building the relationship with external stakeholders except for the product decision area [12,34]. Lastly, proactive environmental strategic firms often seek to gain competitive advantages and lead in the market by taking new 
initiatives aimed at decreasing cost and seizing opportunities [35]. This strategy is the most advanced environmental practice that the firms take environmental issues into account in all management decision areas. Several studies reveal that proactive environmental strategies and responsibility lead to better financial performance [36], environmental performance [33] and corporate performance [37].

\subsection{Insitutional Theory and Resource Based Perspective}

Most literature on the ESs indicated that corporate ESs are dynamic and the underpinning theories explaining this are institutional and resource-based theories [38]. Institutional theory places emphasis on the interaction between the firms and societal stakeholders at a macro level. This theory justifies for the firm's perception and practices in response to emerging environmental issues [39]. The dominant cognition and firms' environmental responses are known as corporate environmentalism. According to this groundwork, the institutional change at the macro level has crucial influence on corporate environmental responses.

Nevertheless, institutional theory is insufficient to explain the reality that the adoption of environment strategy even varies in the similar institutional context, and this variation can be explained by the resource-based view (RBV). Under the light of RBV, the firm's strategy needs to capitalize on its internal strengths and limiting the impact of its weaknesses in order to exploit the external opportunities and accommodates threats $[40,41]$. Therefore, the RBV can be used to explain the different level of environmental strategic adoption through differences in the distinct resources and capabilities of the firm [40].

In sum, a firm's selection of ES is influenced by both the external context and the firm's internal characteristics. A firm's strategic response is shaped by its ability and willingness to adapt to external environments [26]. Hence, merging literatures on internal resource-based characteristics and the institutional context as external environmental issues into a single conceptual model is prominent to reveal the important drivers of corporate ESs.

\subsubsection{Internal Drivers Stimulating the Adoption of Environmental Strategies}

As mentioned above, RBV highlights the link between internal characteristics and a firm's strategies [41,42] or ESs [31,43]. Accordingly, the firm is able to pursue strong ES if they can exploit their VRINE (valuable, rare, inimitable and non-substitutable and exploitable) resources and capabilities. The identification of the bundle of important internal factors can bring value to strengthen the ES for comparative advantages [23].

Tangible and Intangible Resources

The internal drivers that were associated with resources reveal strengths and weaknesses of a given organization [44]. Resources can be divided into two categories, which are tangible and intangible resources [45]. Tangible resources are related to assets that enable firms to enhance their environmental performance and profitability [29]. The intangible resources of the firm are associated with both skills and assets [6,46].

In different approaches, several internal firm characteristics, which are assessed from production process, HR management, leadership and R\&D are also suggested as the internal drivers of environmentally friendly export business strategy [8]. The significant impact of particular resources such as "physical, financial and experiential resources" are also found as antecedents of environmental export marketing strategy [3]. Furthermore, Poisson-de Haro and Bitektine [47] provided strong evidence for effects of core technological elements and non-market capabilities on sustainable development strategy. In addition, organizational learning is also found to be a strong predictor of proactive ES in the study of Aguilera-Caracuel et al. [48]. Other internal factors such as managers' attitudes and perceptions and a firm's export dependence [49] and absorptive capacity [50] are also demonstrated to be significant drivers of corporate environmental practices.

Previous studies have suggested that the necessary tangible resources in performing ESs are financial resources, human resources, physical resources and technological resources [51]. The intangible 
resources of the firm are associated with both skills and assets in different perspectives including managerial support, corporate culture, experiential resources, reputational resources, know-how, chain affiliation, foreign ownership and social capital, and are also suggested to be an internal driver [46] as an important factor of a green strategy [6]. Even though the study of Biçakcıŏglu [6], which was conducted in Turkey, indicated that social capital is perceived as a less important factor compared to other intangible resources, it still suggested to explore the importance of these important resources as drivers of ES adoption in different contexts of emerging economies.

Within the context of developing countries, ES literature has often neglected the critical link between resources and environmental business practices. However, the existence of resource constraints (especially financial, human and technical) were often regarded as seriously obstructing the adoption of environmental strategies. In fact, the limitations in financial resources, insufficient knowledge of green issues and limited access to external consultants can be a considerable obstacle of most firms in ES adoption in developing countries [52,53]. Hence, exploring the importance of these tangible and intangible resources in a new context of an emerging developing country, which have raising concern on environmental issues, is addressed in the present study.

\section{Capabilities}

Capabilities are identified as the firm's ability in integrating, building and reconfiguring the internal and external resources to address changing environments and gaining competitive advantages [54]. The firm's capabilities play an important role in the development of ES and have received great consideration from academicians. For instance, an exploratory study in Canada indicated that three capabilities of stakeholder integration, ongoing learning and continuous innovation were related to proactive ESs [32]. In addition, Teece et al. [54] also identified that the capabilities of cross-functional integration, organizational learning, organizational commitment and employee participation play an important role in the enhancement of the practices of ES and organizational performance. Other dimensions of capabilities such as organizational learning and searching for outside talent, technology and ideas [55] and process innovation [56] were also found as positive antecedents to improve the environmental performance. The study of Sharma and Vredenburg [32], which was conducted in the North American and European ski industry, indicated that organizational capabilities of "shareholder integration, organizational learning, cross-functional integration, continuous innovation, shared vision and strategic proactivity" are positively related to the proactive green strategy development. The recent study by Leonidou et al. [3] has also revealed that capabilities such as "green-export-related shared vision, cross-functional coordination and technological sensing/response" are also found as antecedents of the environmental export marketing strategy.

According to Bıçakcığlu [6], the firm's capabilities can be assessed using the five dimensions of strategic, organizational, relational, knowledge and other based capabilities. However, the other based capabilities, which are assessed in term of time management, transparency and problem solving, were revealed as less important drivers in this study. On the other hand, some of the capabilities dimensions in this study are strongly association with other dimensions. For instance, the relational capabilities seem to be overlapped with the supply chain capabilities, which also emphasize the relational capabilities among members of the supply chain [57], the continuous innovation is considered as a part of $R \& D$ capabilities, absorptive capacity is related to organizational learning, market orientation and R\&D capacity [58]. The dimension of strategic attitudes including strategic proactivity, cross-functional integration and international growth integration are also associated with the depth nature of ESs discussed above and the nature of strategy that is integrating cross-functions in seizing opportunities. Hence, based on the previous studies, the present study focuses on exploring the roles of the most frequently used dimensions of firm capabilities, which are assessed in three types including strategic attitude, organizational capabilities and knowledge based capabilities. Strategic attitude is assessed through shared vision and opportunity cognition, organizational capabilities are assessed based on functions that 
can be presented by R\&D, HRM, Production, Marketing and supply chain capabilities and the knowledge based capabilities are composed of organizational learning, market orientation and technological sensing.

\subsubsection{External Drivers Stimulating the Adoption of Environmental Strategies}

With regard to external drivers, previous studies emphasized the needs and pressures from stakeholders such as public policy makers, customers and other stakeholder groups $[2,6,23]$. In international trade, the needs and pressures from these stakeholders happen in both home or host country. However, prior researchers mostly explored these antecedents from home or host countries perspectives separately $[8,14]$.

In term of home country factors, the first is the legal regulations that represent the orientation of the policy makers. For this issue, Porter [59] extended his firm-level analysis to a macro or governmental level by expanding the scope of the competitive advantage theory from the firm level to the national economy level. Therefore, a home country's legal factors are able to be used for augmenting the efforts of exporters in export promotion and it can be divided into two categories: Intensive policies and enforcement policies. The second factors in the home country result from NGOs' support, one of the most important stakeholders who always take environmental issues and sustainable development into serious consideration $[20,60]$. In previous studies, the prominent drivers associated with and NGO's sponsors programs are suggested as NGO's training programs and sponsor programs $[60,61]$. Based on this relevant literature for the home country perspective, the present study emphasized on exploring the role of the intensive policies and enforcement policies of the home government and NGO's training programs as well as its sponsor programs in stimulating the corporate ESs utilization.

From the host country perspective, the prior scholars indicated the significantly positive impacts of foreign environmental public concern and foreign environmental competitive intensity on ESs [2,8,62]. Other factors such as differences in economic and technological conditions [14]; institutional [63] and NGO's requirement [64] were also found as related to ES adaptation. With this background, the present study extends the current knowledge body by revealing the importance of holistic drivers of regulations, NGO's certification systems, public environmental concerns, competitive intensity and economic development level from the managerial perspective in an emerging country that is facing many typical environment issues in exporting activities.

\section{Research Methods}

\subsection{Methods for Determining the Proactivity Levels and Drivers of ESs}

A qualitative approach was used to explore the proactivity levels of ESs among Vietnam seafood export processing firms and disclose unexplored drivers stimulating these firms to adopt ESs. Specifically, the proactivity levels of firms' ESs were determined following Lee and Rhee's method [12] and the requirements of Circular No. 155/2015/TT-BTC of the Ministry of Finance, Vietnam [65]. According to Lee and Rhee, there are four levels of ES including reactive ES, focused ES, opportunistic ES and proactive ES [12]. These levels of ESs represent different degrees of depth and width subject to managerial perception towards environmental activities. In Vietnam, a listed company has to disclose sustainable development information, that covers six issues: (1) Management of raw materials; (2) energy consumption and water consumption; (3) compliance with the law on environmental protection; (4) policies related to employees; (5) responsibility with the local community and (6) responsibility related to the green capital market [65]. Table 1 provides descriptions of the proactivity levels of ESs, which were determined through analyzing public archival data and interviewing with firm's managers. 
Table 1. Descriptions of proactivity levels of environmental strategies (ESs).

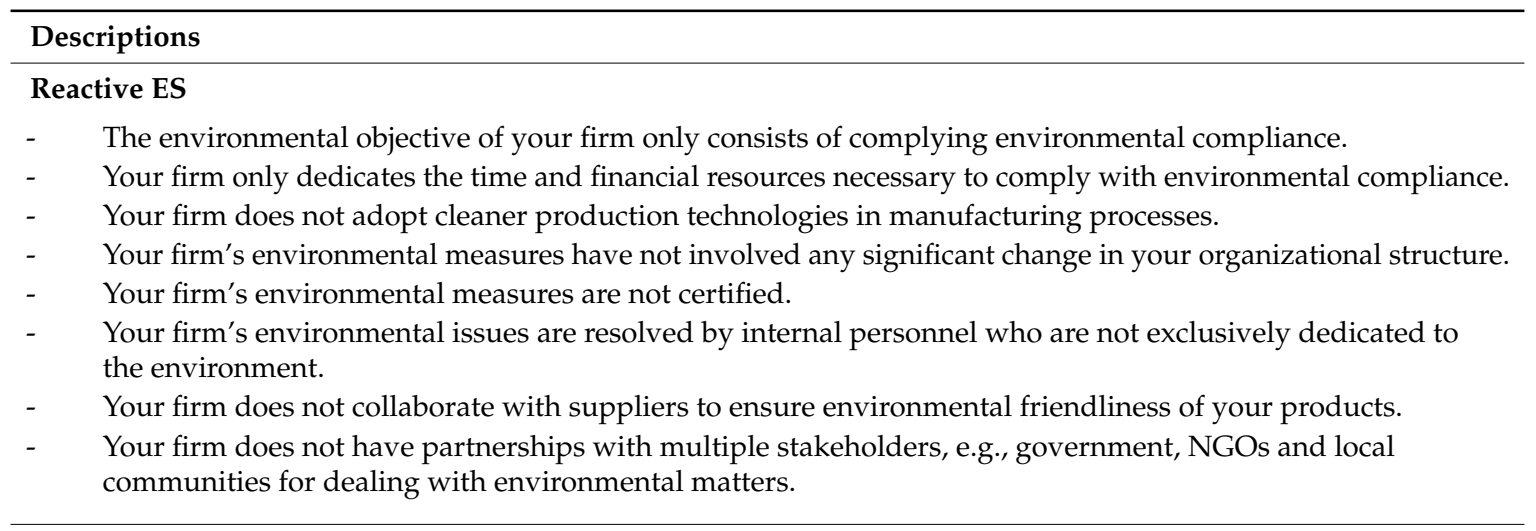

\section{Focused ES}

- The environmental objective of your firm is mentioned in the firm's annual report and sustainable report is integrated in the annual report.

- Your firm dedicates the necessary time and resources to environmental practices to comply with environmental compliance and deal with environmental pressures from other stakeholders.

- Cleaner production technologies have been adopted in your firm's manufacturing processes.

- Your firm's environmental measures have required modification of work methods and/or organizational structure.

- $\quad$ Some your firm's environmental measures are certified or are in the process of being certified.

- Your firm's environmental issues are resolved by qualified internal personnel who are exclusively dedicated to the environment and/or regular external environmental professionals.

- Your firm does not collaborate with suppliers to ensure environmental friendliness of your products.

- Your firm does not have partnerships with multiple stakeholders, e.g., government, NGOs and local communities for dealing with environmental matters.

\section{Opportunistic ES}

- The environmental objective of your firm is stated clearly in the firm's annual report, where the sustainable report is integrated in and follows the requirements of Circular No. 155/2015/TT-BTC of the Ministry of Finance.

- Your firm dedicates the significant time and resources to environmental practices to comply with environmental compliance and to deal with environmental pressures from other stakeholders.

- $\quad$ Your firm has developed and adopted cleaner production technologies in manufacturing processes.

- Your firm's environmental issues have significant change in work methods and/or organizational structure.

- Most of your firm's environmental measures are certified.

- Your firm's environmental issues are resolved by qualified internal personnel who are exclusively dedicated to the environment and/or regular external environmental professionals.

- Your firm has good collaborations with suppliers to ensure environmental friendliness of your products.

- Your firm has partnerships with multiple stakeholders, e.g., government, NGOs and local communities for dealing with environmental matters.

\section{Proactive ES}

- The environmental objective is one of the priority objectives of your firm, and your firm's annual report have a sufficient part of the sustainable report, that follows the requirements of Circular No. 155/2015/TT-BTC of the Ministry of Finance.

- Your firm dedicates important budgets to environmental practices that go beyond complying with environmental compliance and pressures from other stakeholders.

- Your firm applied cleaner production technologies in all manufacturing processes.

- Your firm's environmental issues are highly relevant to both work methods and organizational structure.

- $\quad$ All of your firm's environmental measures are certified.

- Your firm has an environmental department that is organized to cope with the firm's environmental issues.

- Your firm has good collaborations with suppliers to ensure environmental friendliness of your products.

- Your firm has good partnerships with multiple stakeholders, e.g., government, NGOs and local communities for dealing with environmental matters. 
Previous studies suggest that exploring the drivers of firms' ESs including institutional factors and the firms' internal characteristics through managerial perceptions is a meaningful and prominent approach $[2,6,12,31]$. In this study, the drivers of firms' ESs were therefore determined through analyzing data from interviews with managers of Vietnamese seafood export processing firms. Factors that motivate ESs were determined based on occurrence frequency and further clarified through discussions with the respondents in the interviews.

\subsection{Data Collection}

Data was collected from two sources: (1) Public archival data; and (2) semi-structured interviews.

\subsubsection{Public Archival Data}

In order to generate the overall picture of proactivity levels of ESs adopted by Vietnam seafood export processing firms, the research team utilized secondary data from a public source. Public archival data was collected through Annual Reports, year 2017 and 2018 and/or Annual Sustainable Reports, year 2017 and 2018 of 32 listed seafood export processing firms on the Vietnam Stock Exchange Market (Appendix A). In Vietnam, a listed company may set up its own Sustainable Report or present it in the Annual Report and it has to disclose sustainable development information as the requirements of Circular No. 155/2015/TT-BTC of the Ministry of Finance. As previously mentioned, the content that a listed company must report on environmental and social impacts covers six issues relating to raw material management, energy consumption, compliance with environmental laws, employee policies, responsibilities with the local community and green capital market [65]. Therefore, in Annual Reports year 2017 and 2018 and/or Annual Sustainable Reports year 2017 and 2018 of 32 listed seafood export processing firms, data on the six issues along with information on corporate objectives; process of manufacturing; organizational system; supply chain; external relationship with regard to corporate environment, society and community sustainable were investigated

\subsubsection{Semi-Structured Interviews}

Semi-structured interviews were conducted with seafood export processing firms (the main actors in Vietnam seafood chains) in the Mekong Delta region — the seafood heart of the country [18] —from November 2018 to March 2019 and the Northern East of Vietnam in April 2019 by the research team. Based on discussions with experts in the seafood sector, five provinces in Mekong Delta (Can Tho, Tien Giang, Hau Giang, An Giang and Dong Thap) and two provinces in the Northern East of Vietnam (Quang Ninh and Hai Phong) were chosen because of the high level of concentration of Vietnam seafood export processing firms there. The research team made three visits, each lasted five days to the Mekong Delta and two visits to Northern East of Vietnam to collect data.

In the beginning, with the referral from the Ministry of Industry and Trade, the research team had meetings with seven Departments of Industry and Trade of the seven chosen provinces. A list of seafood export processing firms in each chosen province was provided in each meeting. Owing to the help of officers in each Department of Industry and Trade, lists of seafood export processing firms were filtered out based on green related activities. Accordingly, only firms with green related activities were retained as targeted respondents. The research team then contacted these firms by email and phone to explain the purposes of the study and request them to voluntarily participate in the interviews. The extant literature suggests that drivers of firms' ESs should be explored from different managerial perceptions [2,6]. A snow-ball technique [16] was therefore used, whereby the interviewed respondents were asked to identify other potential respondents. Using this approach, 44 managers from 28 Vietnam seafood export processing firms (Appendix B) were interviewed. Based on the ES theoretical background, the respondents were asked two main parts. The first part of interviews focused on describing the ESs that their companies were adopting. The second part concentrated on driving factors that motivated their company to choose that strategy. Interviews lasted from one hour to two hours. 
It should be mentioned that out of 28 firms that agreed to take part in the interviews, 16 firms had two respondents being interviewed. The research team carefully compared and analyzed the answers of respondents from these 16 firms to determine the appropriate proactivity levels of ESs adopted by the firms. Importantly, the answers of respondents from the same firm were complement of each other, enabling the research team to explore the various drivers of their firm's ESs from different managerial perceptions as suggested in the extant literature $[2,6]$. In general, there were consistencies in the proactivity levels and drivers of ESs identified by the respondents from the same firm.

After recording all interviews, content analysis that consisted of three distinct steps was used. The first step (open coding) began with identifying preliminary concepts of ESs and types of ESs. The second step then classified them into categories (i.e., internal factors, home country's factors and host countries' factors) and sub-categories. The third step (axial coding) was finally processed by searching for linkages among categories to divide them into topics. NVivo 10.0.638 software (QSR International, Australia) was used in these steps to assist in coding text in a hierarchical theme. The following sections will present the results of the empirical investigation.

\section{Research Results}

\subsection{The Proactivity Levels of ESs Adopted by Vietnam Seafood Export Processing Firms}

At the time of analyzing in April 2019, most of the investigated firms had integrated sustainable reports in their annual reports and followed the required contents of Circular No. 155/2015/TT-BTC. No investigated firms presented their own sustainable reports according to GRI standards-the first global standards for sustainability reporting and some reports have not improved significantly between 2017 and 2018. Findings from sustainable report parts in Annual Reports of 32 listed firms and 44 interviews revealed the levels of proactivity of these firms' ESs as in Figure 1.

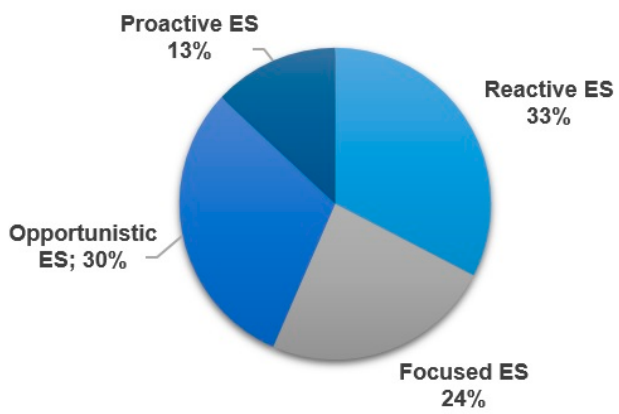

Figure 1. The levels of proactivity of Vietnam Seafood Export Processing Firms to ESs.

The result showed that reactive ESs were adopted most (33\%) by Vietnam seafood export processing firms, following by opportunistic ESs (30\%), focused ESs (24\%) and proactive ESs (13\%), respectively.

Reactive ESs, which are formulated for compliance with environmental regulations, emphasize on the minimization of risk, liabilities and cost, were the choice of most of the investigated firms. These companies' environmental practices were at a low level [12] as respondents stated:

" ... improving the quality of products to fit the environmental requisitions are our tasks to access to international markets. We have to consider environment activities to avoid the numbers of shipments being warned by key international importers"-12A.

“... Both direct and indirect cost of getting ISO 14001 certificate is our considerations since we are small in size. Financial burden indeed is the obstacle that made us reactive to environment requirements"-17A

Focused ESs are strategies focusing on a narrow commitment level of environmental issues in manufacturing product, organizational system, supply chain and other external relationships. Twenty four percent of investigated firms adopted focused ESs. This strategic group implements environmental 
activities within a company and cares less about doing environmental activities outside of the firm with the connections with external stakeholders [12]. One respondent specified:

“... to overcome ecological barriers to access to sensitive international markets, we have used cleaner production technology in our manufacture process and had many environmental training programs for our staffs. However, we have not been developing good partnerships with external stakeholders, such as suppliers, government, NGOs, local community"-25B.

Opportunistic ESs accounted for 30\% of investigated firms. Vietnam seafood export processing firms, who adopted opportunistic ESs focus on developing environmental activities outside a company's boundary. They undertook much higher interest in building the relationships with external stakeholders such as suppliers, government, and local community as in the research of Lee and Rhee [12]. Since the Vietnam seafood value chain shows close association among four main categories of operators: Input suppliers, farmers, traders and processors/exporters [64], environmental strategies of export processing firms - the last operators in the chain-will depend much on implementing environment activities of other operators. One manager explained:

“Deciding to pursue an environmentally friendly business strategy, we focus on controlling our supply chain in green. Building a closed supply chain, ensuring environmental friendliness from breeding, farming and processing is our goal. Establishing relationships and encouraging other stakeholders in the chain to ensure greenness in their operations has helped us to get truly environmentally friendly products and be welcomed by fastidious markets ... Anyway, managerial supports from top management are the key for our ES"-13A.

Proactive ESs is the highest level of environmental strategies that cover wide range of environmental commitment in manufacturing products; organizational system; supply chain and other external relationships [12]. The main objectives of proactive ESs are going beyond competitors by taking initiatives on new practices/products, seizing environmental related opportunities or reaching green competitive advantages [35]. The number of Vietnam seafood export processing firms in the sample who adopted proactive ESs was modest (13\%). They were the larger size firms with long history of operation and are pioneers in ESs.

"Going beyond competitors in green innovations becomes our company's norm. We extract a portion of the profits to invest in social enterprises-a collection of shrimp farmers-to ensure all farming processes are environmentally friendly; At the same time, to ensure the purchase of all these households' shrimp at a higher price."-6B. "Implementing ES is a main vision of our company. In our top managers' beliefs, the blue eco label on all product lines is our responsibility in order to increase the image of company in both domestic and international markets."-1A.

\subsection{Drivers of Vietnam Seafood Export Processing Firms' Environmental Strategies}

\subsubsection{Internal Factors}

A comprehensive understanding of resources and capabilities is necessary for firms in order to formulate and implement ESs and improve both market and financial performance [4]. The internal drivers frequently indicated specific resources and capabilities, which provide foundations for a firm's ES.

\section{Resources}

Frequency indicated the key strategic resources motivating Vietnam seafood export processing firms in the attempt to pursue ESs by the respondents were three tangible resources (financial, human and technology resources) and three intangible resources (managerial support, chain affiliation and corporate culture) (Table 2). Among tangible resources, financial resource was the driver motivating of ESs the most. 
Table 2. Resources that motivate ESs.

\begin{tabular}{cccc}
\hline Categories & Second-Order Concepts & First-Order Concepts & Frequency \\
\hline \multirow{4}{*}{ Tangible resources } & Financial resources & 38 \\
& Human resources & 18 \\
& Physical resources & 8 \\
& & Technological resources & 18 \\
\cline { 2 - 4 } Resources & Managerial support & 42 \\
& Intangible resources & Corporate culture & 38 \\
& & Experiential resources & 8 \\
& & Reputational resources & 7 \\
& Know-how & 4 \\
& Chain affiliation & 40 \\
& & Foreign ownership & 0 \\
\hline
\end{tabular}

The empirical evidence was notable and confirmed the study of Bowen [51] who emphasized the vital role of financial resources in applying environmental operations. One CEO of a shrimp exporter stated: "We think that finance is the most important tangible resource to change our manufacture to environmental operation in pursuing ES. We did extract our profits to invest in green manufacture towards sustainable development"-10B. Another manager of a catfish processor also emphasized: "In order to get success in international markets in long term, we did volunteer to distribute our financial resource to invest in shifting our strategy towards green"-8A.

Human resources and technological resources were the second drivers influencing ESs of Vietnam seafood export processing firms with the confirmation of 18/44 respondents. Answering the question of assessing technology resources of Vietnam seafood export processing firms, one manager specified: "We use cleaner production technologies that meet the standards set by the fastidious importing countries like the US, Japan and EU. These technology resources have motivated us towards ES for sustainable development"-18A. Another manager explained: " ... human resources are very important for us. Because of having good human resources, our company can easily move on environmental strategies to satisfy fastidious markets"-1B.

Among intangible resources, managerial support was the most influential factor to Vietnam seafood export processing firms' ESs, confirmed the study of Quazi et al. [52] and Fernández et al. [53]. Emphasized at the vital role of managerial support and corporate culture, respondents stated: "Our top management concern for the natural environment is very strong and therefore we soon adopted the ISO14001 standard towards ES"—-9B; and "If you have full supports from top managers, you can easily develop green corporate culture like us and focus on ES"-25B.

The interviews also demonstrated the important role of chain affiliation in shifting Vietnam seafood export processing firms' strategies to green as explanations of respondents. “ . . the biggest challenge of Vietnam pangasius industry is the breed. Moreover, the connection among processors, farmers and seed suppliers is still fragmented. Only a tight link in chain affiliation helps our firm turn to green strategy"-7A; " . . For pangasius and shrimp products, Vietnamese enterprises have complied with the sustainable farming standards of the world in controlling from seed, production lines to final products. Therefore, chain affiliation is the driver motivating our environmental strategy"-26B.

Capabilities

Strategic attitude, operational capabilities and knowledge based capabilities were three types of capabilities that emerged from interviews (Table 3). 
Table 3. Capabilities that motivate ESs.

\begin{tabular}{cccc}
\hline Categories & Second-Order Concepts & First-Order Concepts & Frequency \\
\hline \multirow{4}{*}{ Strategic Attitude } & Shared vision & 18 \\
& & Opportunity recognition & 30 \\
\cline { 2 - 4 } Capabilities & Operational & R\&D capabilities & 16 \\
& & Production capabilities & 26 \\
& & Marketing capabilities & 24 \\
& & Supply chain capabilities & 14 \\
& \multirow{3}{*}{ Knowledge based } & Organizational learning & 18 \\
& & Market orientation & 16 \\
& & Technological sensing & 8 \\
\hline
\end{tabular}

Interviews revealed that shared vision and opportunity recognition were drivers that motivated ESs of Vietnam seafood export processing firms. For instance, opportunity recognition was emphasized as an important capability stimulating ESs, which implied that these firms considered environmental issues as market opportunities as in previous research- [66]. One manager explained: "I am very excited when realized that there are many unexploited market opportunities when our company shifts to ES"-15B; or the share of a manger from 20A: "I discover previously unnoticed market opportunities of implementing ES in international markets". Moreover, a visionary leadership with long-term commitment and investment is necessary for pursuing ESs [67]. The frequency of shared vision in participating companies indicated the positive influence of it in shifting the company towards ES as the explanation of a manager: "In our corporate agenda, the priority of eco label and sustainable development in shared vision leads our top managers, functional managers in all departments and divisions toward environmental goals" $-14 \mathrm{~A}$.

Organizational capabilities are the way of using of the firm's assets in the most efficient and competitive ways $[68,69]$ and can be divided to operational capabilities and dynamic capabilities. The most acknowledged operational capabilities by the participating Vietnam export processing firms were human resource management (HMR) capabilities, production capabilities and supply chain capabilities. A majority of the interviewees explained the role of HMR: "More than $68 \%$ of our workforce has participated in safety food and environmental certification events. Their knowledge about eco products made our company easily to adopt ES"-15A. Production and R\&D capabilities were also emphasized in the response of one manager: " ... confident in production capabilities as well as R\&D, our company has adopted environmental strategy to exploit higher added value in international markets."-19A. Furthermore, one manager specified about supply chain capabilities in motivating ESs: "We have good and close relationships with many suppliers. All of our suppliers understand that they must reduce the environmental impact in all manufacturing processes, compliance to standards of our international markets ... These supply capabilities help our company move to green strategy"-22A.

Knowledge base capabilities help companies sensing, addressing and exploring environment dynamics [70]. In this research, organizational learning, market orientation and technological sensing were among knowledge-based capabilities that encouraged the implementation of ESs in Vietnam seafood export processing firms. One manager stated: "The environmental training programs of NGOs and local communities have opened our staffs to fresh and meaningful perspectives. Organizational learning truly drives our company to ES. Moreover, our ES is also resulted from green market orientations in international markets"-10B.

\subsubsection{Home Country's Factors}

Since a competitive advantage was extended from firm competitive advantage to national competitive advantage by Porter [59], home country's factors become influential factors that increase 
the efforts in promotion of exporters. Home country's factors can be divided into two categories: Home country institutions and NGOs support. Frequency indicated key home country's drivers of Vietnam seafood export processing firms' ESs were NGO's training programs and NGO's sponsor programs (Table 4). The results showed the role of government in encouraging Vietnam seafood export processing firms is limited and the role of NGOs support is greater than the role of government.

Table 4. Home country's factors that motivate ESs.

\begin{tabular}{cccc}
\hline Categories & Second-Order Concepts & First-Order Concepts & Frequency \\
\hline \multirow{2}{*}{$\begin{array}{c}\text { Home country's } \\
\text { Factors }\end{array}$} & $\begin{array}{c}\text { Home country } \\
\text { institutions }\end{array}$ & $\begin{array}{c}\text { Government incentive policies } \\
\text { Government enforcement policies }\end{array}$ & 10 \\
\cline { 2 - 4 } & \multirow{2}{*}{ NGOs supports } & NGOs' training programs & 28 \\
& & NGOs' sponsor programs & 22 \\
\hline
\end{tabular}

Home Country Institutions

Main government authorities that shape the institutional framework for Vietnamese seafood industry include: Ministry of Agriculture and Rural Development (MARD); Ministry of Industry and Trade (MOIT) and The Vietnam Certification Centre (QUACERT). With regard to governance of the seafood industry, MARD consists of four most important offices: (1) Directorate of Fisheries (DoF), mainly responsible for the overall management and building policy and regulations; (2) National Agro-Forestry-Fisheries Quality Assurance Department (NAFIQAD), responsible for quality control and food safety; (3) Department of Animal Health (DoAH), responsible for monitoring and regulating the use of medicines and chemicals in the aquaculture sector and (4) the National Centre for Agriculture and Fisheries Extension, responsible for monitoring the compliance with regulations and applying sanctions for regulation violations at the provincial level. MOIT is focused on state management of the exporting and importing seafood companies. QUACERT is an office of the Ministry of Sciences and Technology, authorized to provide services including certification of management systems to international standards, foreign standards and Vietnam standards [5].

Similar to findings in other research of governance of Vietnam aquaculture, interviews also revealed that the Vietnam seafood chain is heavily regulated by the Vietnam government. Home government continues to be highly supportive of seafood development in Vietnam. In response to heighten stringency of seafood environmental standards, the Vietnam government from the center to provinces enact and enforce stricter inspection and monitoring systems. However, governance ability of the government to ensure that Vietnam seafood all met environmental requirements to maintain access to fastidious markets is limited. Several reasons were pointed out as government's policies are a lack of enforcement and poor market incentives to farmers and processors [17]. Moreover, processors/exporters depend much on raw shrimp/fish from aquaculture farmers and traders but with thousands of small-scale farmers and traders that are unregistered, government exerted control is just starting at the farm gate [64]. Therefore, even though the Vietnam government has a vital role in the seafood sector and has recently issued both incentive and enforcement policies, the influence of it to ESs of Vietnam seafood export processing firms is limited since the majority of interviewees referenced the smaller impacts of those policies. One manager explained: "Vietnam government has issued incentive policies motivating seafood companies pursue eco-label products. However, we don't think that government policies can help us much in ESs because it is not realistic. We need more supports from government"-21B. Another manager expressed: "NAFIQAD has an important role in seafood sector by regulating the inputs of medicines and chemicals, preventing the use of forbidden substances, etc. However, we think that the validity of policies is not strong enough to force seafood export processing firms toward ES"-3A. 


\section{NGOs' Supports}

NGOs' supports in Vietnam included NGO's training programs and NGOs' sponsor programs. In recent years, NGOs have played a crucial role in an effort to train farmers, workers and managers of seafood chains as well as sponsor them to adapt to environmental strategies. For instance, the Sustainable Trade Initiative and the Netherlands Development Organization are setting up an aquaculture platform to promote sustainability of Vietnam aquaculture sectors; WWF/ DANIDA is promoting certification for shrimp by supporting small-holders in standard development and costs for Aquaculture Stewardship Certification in the Mekong Delta; International Climate Initiative, Nature Conservation and Nuclear Safety are supporting for organic shrimp farming projects in combination with protection of mangrove forests in Ca Mau, etc. [5,71]. These NGO's projects are motivations for Vietnam seafood export processing firms to adopt ESs. Appreciating the supports of NGOs, one manager said: "NGOs in Vietnam have not only hosted many environmental training events but also sponsor to farmers, who are the most vulnerable actors and are confront with higher risks than the other actors along the chain, to upgrade their producing conditions towards environmentally friendly. NGOs' supports stimulate us to ESs as our products depend much on farmers"-24A. Furthermore, one manager explained: "NGOs' supports are more meaningful for farmers and processors than those of Vietnam government. They did motivate us to change to ESs"-10B.

\subsubsection{Host Countries' Factors}

Remarkably, inter-governmental and international NGOs have been responsible for setting the international framework of environmental regulations for seafood production over the last years [17]. Interviews with 44 executive managers from 28 seafood export processing firms revealed that host countries' regulations, NGOs' certification systems, public concerns and competitive intensity were host countries' factors that motivated ESs of Vietnam seafood export processing firms (Table 5).

Table 5. Host countries' factors that motivate ESs.

\begin{tabular}{ccc}
\hline Second-Order concepts & First-Order Concepts & Frequency \\
\hline & Host countries' regulations & 32 \\
& Public Environmental Concerns & 30 \\
Host countries' Factors & NGOs' certification systems & 32 \\
& Competitive Intensity & 28 \\
& Economic Development Level & 6 \\
\hline
\end{tabular}

Host Countries' Regulations

Most of the interviewees confirmed the importance of host countries' regulations as drivers that stimulate the adoption of ESs. Hazard analysis critical control points (HACCP), minimum required performance limits (MRPLs) and the food safety basic law are typical risk assessment approaches and food safety principles that many governments are based on to set their standards and regulations. Since governmental standards and regulations are more stringent, we witness the higher number of producer inspections, product detention and product rejection by importing governments. If authorities of importing countries detect food safety violations from one exporter, not only that exporter's original shipment but all future shipments will be immediately rejected. Furthermore, all seafood shipments from that exporter's country will be in a watch list and additional scrutiny will be placed on [64]. In response to the regulatory power of host countries on food safety standards, a number of Vietnam seafood export processing firms have taken a proactive strategy, trying to place high quality value-added lines or changing their strategies toward green. One manager specified: “ . . increasing stringency of foreign countries' governmental regulations in food safety and environmental sustainability put our company under pressure of changing our strategy towards sustainability. ES thus is our strategic choice to access to lucrative markets like US and EU"-5A. 


\section{Public Environmental Concerns}

Skyrocketing demand for seafood worldwide generates considerable environmental problems for the aquaculture industry. Thus, parallel to governmental regulations, different stakeholders have introduced initiatives to promote sustainable fisheries and aquaculture. Recently, different NGOs, aquariums and some retailers have banded together to develop strategies targeted at using public concern over food safety and environmental sustainability, ranging from consumer campaigns to eco-labels [72,73]. For instance, a UK-based NGO has cooperated with some retailers like Costco exploring shrimp processing in more responsible ways. NGOs in the US recently have targeted consumers with environmental and social implications of seafood campaigns [64,73,74]. Together with consumer campaigns, public environmental concerns also increased by the eco-label promotions. These promotions aim to educate consumers about the environmental effects in order to change their purchasing behaviors toward green. Interviews revealed the majority of Vietnam seafood export processing firms considered public environmental concern as a driver motivates firms to ESs. One manager specified: "Shifting export strategy towards green is our way to develop green image to attract more ecologically conscious customers and also to confront with international government intervention"-19B. Another manager also confirmed: "Accessing to countries characterized by a high level of public environmental concerns, such as EU countries, environmentally friendly strategy is our choice"-2B.

\section{NGOs' Certification Systems}

Despite increasing stringency of governmental regulations, many NGOs showed their disillusion with the failure of government regulations to improve seafood production toward green. Besides organizing campaigns to raising the ecological consciousness of consumers, governments and retailers/corporations to encourage the adoption of green products, many NGOs have been successful in slowly driving the seafood industry towards an environmental certification system [64]. Recently, ACC (Aquaculture Certification Council), ASC (Aquaculture Stewardship Council) and GLOBAL G.A.P. (Good Agriculture Practices) are three of the most important certificates among more than 30 certification types for aquaculture [1]. In terms of environmental certifications, Friend of the Sea (FOS) and Marine Stewardship Council (MSC) certificates are the most popular eco-labels for seafood worldwide [75,76]. Major retailers in international markets has accepted these NGOs' certificates as main standards to access to their chains, thus NGOs' certification system has become important drivers for ESs of seafood export processing firms. From a governance perspective of the seafood chain, it is important to recognize that export processing firms need to consider NGOs' certification systems along with governmental regulations on environmental issues as one manager stated: "Monitoring and updating both governmental regulations and NGO certification requirements in the US and EU markets are our priorities now. We investigated to understand how these regulations and certification systems affect to our access to strategic markets. We have adopted ES since seafood with eco label is welcomed in developed markets"-3A. Another manager explained: "Bearing the blue MSC label on products, our competitors benefit a price premium, and easily gaining market access. They are good motivations for us to change to $\mathrm{ES}^{\prime \prime}-1 \mathrm{~B}$.

\section{Competitive Intensity}

Valued at USD 362 billion with a large number of high ecologically conscious buyers and a large number of producers worldwide, competitiveness in the seafood global market is at a high level [1]. Vietnam seafood exporters have seen their competitive position change frequently in recent years. Interviews showed that Vietnam seafood export processing firms have gradually shifted from price competition into quality competition. They have made many efforts to overcome technical and environmental barriers of importing countries by improving the quality of seafood products and an eco-label seafood product is one amongst them. One manager explained: "Under fiercer competitive conditions, customers have more choices of seafood. India, China, and Thailand are 
our main competitors. Shifting the company to green strategy is our way to avoid facing direct competition from international competitors by enhancing our customer loyalty to environmentally friendly manner"-2A.

\section{Discussions and Implications}

The main objectives of our research are examining the levels of proactivity of ESs and exploring driving factors that encourage Vietnam seafood export processing firms to implement ESs under certain theoretical paradigms. The results of the study revealed that reactive ESs were adopted most $(33 \%)$ by Vietnam seafood export processing firms, following by opportunistic ESs (30\%), focused ESs (24\%) and proactive ESs (13\%), respectively. Furthermore, with respect to influencing factors, internal and external factors in both home country and host countries appeared to encourage these firms to adopt ESs. These empirical findings support proposition 1 and proposition 2.

The first finding revealed differences among environmental strategic types of Vietnam seafood export processing firms. Based on interviews in the same regulatory context of single industry, we found out different characteristics of each environmental strategy. Among those characteristics, managerial support from top management is one of the most important factors influencing the level of proactivity of ES, consistent with the research of Aragon-Correa [27]. Managers have great responsibility for matching resources and capabilities of firms to adapt to external challenges. Therefore, a proactive level of environmental strategies relies on managerial support from top management. Furthermore, firm size and firm age are also influential factors to distinguish more environmentally proactive strategies to reactive ones. It is in harmony with the empirical research of Sharma [31].

The second finding consisted of identifying drivers of ESs of Vietnam seafood export processing firms. Based on research results, these firms need to investigate certain resources (financial resources, human resources, technological resources, managerial supports, chain affiliation and corporate culture) and particular capabilities (opportunity recognition, HMR capabilities, production capabilities and supply chain capabilities) when employing ESs to be more effective. Amongst internal factors, managerial supports, chain affiliation and corporate culture are three most influent drivers of ESs. This finding is in harmony with empirical studies of green strategies for export companies conducted by Biçakcioğlu [6] and Leonidou et al. [8,23]. However, chain affiliation in this study revealed to be more influential to the adoption of ESs in comparison to previous research in a different research context. This implied the typical fragmented characteristics of seafood chains' governance pose a significant obstacle for Vietnam seafood export processing firms to pursue ESs [18]. On the other hand, external factors in both home country and host countries are also important determinants for Vietnam seafood export processing firms' ESs. Regarding home country's factors, the results showed the role of the government is limited in comparing to the role of NGOs supports in Vietnam. This study is in contrast with previous related studies when they almost focused on the critical role of home government $[4,6,8]$. Furthermore, host countries' regulations, NGOs' certification systems, public environmental concerns and competitive intensity are key considerations when formulating and implementing ESs because they can seriously affect the operations of Vietnam seafood export processing firms in international markets. The effect of each host countries' factor might be different when a company operates in different markets.

In terms of literature, our research contributed in several ways. First, this study derived Vietnam seafood export processing firms' four ES levels of proactivity, which were identical to four types that Lee and Rhee [12] suggested: Reactive, focused, opportunistic and proactive ES. As stated in proposition 1, the reactive ES, which showed the lowest level of environmental commitment, accounted for largest number of Vietnam seafood export processing firms. In contrast, proactive ES showed the highest level of commitment to environmental issues but accounted for the fewest number of Vietnam seafood export processing firms. Second, this study explored the untouched side of companies' ESs when exporting seafood to international markets in the same regulatory context of a single industry. Since previous studies have discovered a number of fragmented factors that motivate ESs in general without focusing on the characteristics of a single industry, this study explored prominent internal and external 
drivers in both home and host countries from different stakeholders' perspectives (firms, competitors, suppliers, government, NGOs and consumers) to encourage Vietnam seafood export processing firms to pursue and implement ESs. Third, this study affirmed the arguments of resource-based view and institutional theories that the adoption and selection of ESs are affected by both external context and the firm's internal characteristics $[49,68,69]$. Fourth, this study provided characteristics of ESs for companies in the seafood industry in an emerging market. Since this topic has been unexplored in other research, our study demonstrated to what extent for future research.

Regarding managerial implications, our research provided practical implications for Vietnam seafood export processing firms by exploring which drivers stimulate ESs in their export operations. Considering ES as a value-creating strategy and promoting an ES to be successful, they should concentrate on suitable resources and capabilities. Firstly, they should gradually reallocate financial, human, technological resources and chain affiliation toward supporting environmental initiatives. At the same time, developing capabilities, such as opportunity recognition, HMR capabilities, production capabilities and supply chain capabilities to support ESs is very important for these firms. Secondly, it should be realized that scanning external factors in both home and host countries is very important to realize challenges and opportunities for firms to pursue ESs. The increasing regulations relating to environmental protection from host countries, the growing certifications from global NGOs, the heightened ecological conscious public concerns and the more intensity competition make the adoption of ESs critical, in order to take competitive advantages of differentiation and improve their market and financial performance. However, the research results emphasized the limited role of the Vietnam government in supporting Vietnam seafood export processing firms to adopt ES even though the government has issued both incentive and enforcement policies for green activities. Based on this research result, public policymakers need to communicate with seafood export processing firms to deeply understand their obstacles in pursuing ESs and build more realistic policies that can convince Vietnam seafood export processing firms to adopt ESs.

\section{Conclusions and Future Research}

Using public archival data from 32 Vietnam listed seafood export processing firms and semi-structured interview data from 44 respondents who were managers from 28 seafood export processing firms, this study revealed that reactive ES were adopted the most by Vietnam seafood export processing firms, followed by opportunistic ESs, focused ESs and proactive ES, respectively. Furthermore, the results showed that internal and external factors in both home and host countries were motivations of the adoptions of ESs among these firms. The findings provide several important practical implications for both export companies and policymakers in Vietnam.

However, there were several limitations in this study, mainly related to the research setting. First, this qualitative research needs to be validated statistically for further study [77]. Nevertheless, this research results provided initial insights to explore drivers of ESs in a single industry within the same regulatory international trade context, which may be a starting point for further studies. Second, as investigated companies in this research were limited at a listed company on the Vietnam Stock market, an expanded sample for research is necessary.

Therefore, several areas for further research are suggested. First, these qualitative findings can be validated statistically by a quantitative methodology approach in future research. Second, an integrated framework of antecedents, process and consequences of Vietnam seafood export processing firms' ESs can be investigated. Third, the effect of each stakeholder in the seafood value chain on the adoption of ESs could solely concentrate on. Fourth, a longitudinal study to see the impact of ESs on firms' performance should be a topic. Fifth, future studies could also make investigations in different industries on the adoption of ESs or making comparatives in different industries and in different countries. Finally, given that the motivating factors of reactive and proactive ESs are different, future research should conduct a comparative analysis between drivers of the ESs in relation with particular proactivity levels. 
Author Contributions: Conceptualization, B.D., U.N., N.N. and L.W.J.; methodology, B.D.; formal analysis, B.D.; investigation, B.D. and U.N.; writing-original draft preparation, B.D., U.N. and N.N.; writing-review and editing, B.D., U.N., N.N. and L.W.J.; funding acquisition, B.D.

Funding: Research for this paper is part of the project "Research on environmentally friendly export business strategies of Vietnam seafood enterprises on some key markets"-Code KX 201, funded by the Ministry of Education and Training and Thuongmai University, Vietnam.

Acknowledgments: The authors would like to thank the officers of Ministry of Industry and Trade for their support in the data collection.

Conflicts of Interest: The authors declare no conflict of interest. The funders had no role in the design of the study; in the collection, analyses, or interpretation of data; in the writing of the manuscript, or in the decision to publish the results.

\section{Appendix A}

Table A1. Listed seafood export processing firms in Vietnam Stock Exchange Market for public archival data.

\begin{tabular}{|c|c|c|c|c|c|}
\hline No & $\begin{array}{l}\text { Securities } \\
\text { Symbol }\end{array}$ & Trade Name of Firm & $\begin{array}{l}\text { Sustainable } \\
\text { Report }\end{array}$ & Annual Report & $\begin{array}{l}\text { Integrated } \\
\text { Sustainable Report } \\
\text { in Annual Report }\end{array}$ \\
\hline 1 & AAM & MEKONG FISH & No & Yes & Yes \\
\hline 2 & $\mathrm{ABT}$ & AQUATEX BENTRE & No & Yes & Yes \\
\hline 3 & $\mathrm{ACL}$ & CL-FISH Corp & No & Yes & Yes \\
\hline 4 & AGF & AGIFISH Co. & No & Yes & Yes \\
\hline 5 & ANV & NAVICO & No & Yes & Yes \\
\hline 6 & AVF & ANVIFISH Co. & No & Yes & Yes \\
\hline 7 & BLF & BACLIEUFIS, JSC & No & Yes & Yes \\
\hline 7 & CAD & CADOVIMEX & No & Yes & Yes \\
\hline 8 & CAT & SEAPROMEXCO & No & Yes & Yes \\
\hline 9 & CASES & $\begin{array}{l}\text { CAMAU SEAFOOD } \\
\text { PROCESSING., JS }\end{array}$ & No & Yes & Yes \\
\hline 10 & CASEAMEX & CANTHO SEAMEX & No & Yes & Yes \\
\hline 11 & CLP & CUULONG SEAPRO & No & Yes & Yes \\
\hline 12 & CMX & CAMIMEX GROUP & No & Yes & Yes \\
\hline 13 & DAT & TRISEDCO & No & Yes & Yes \\
\hline 14 & FBT & FAQUIMEX & No & Yes & Yes \\
\hline 15 & FMC & FIMEX VN & No & Yes & Yes \\
\hline 16 & FSO & FISHIP CO & No & Yes & No \\
\hline 17 & KSE & KHASPEXCO & No & Yes & No \\
\hline 18 & ICF & INCOMFISH & No & Yes & Yes \\
\hline 19 & IDI & I.D.I & No & Yes & Yes \\
\hline 20 & IDC & IDICO & No & Yes & No \\
\hline 21 & TS4 & Seapriexco No.4 & No & Yes & Yes \\
\hline 22 & VHC & VINH HOAN CORP & No & Yes & Yes \\
\hline 23 & CAN & Halong Cafoco & No & Yes & No \\
\hline 24 & NGC & NGO PREXCO & No & Yes & Yes \\
\hline 25 & $\mathrm{VNH}$ & VISEA CORP & No & Yes & Yes \\
\hline 26 & SJ1 & $\begin{array}{l}\text { Hung Hau Agriculture } \\
\text { Corp. }\end{array}$ & No & Yes & Yes \\
\hline 27 & JOS & Minh Hai Jostoco & No & Yes & Yes \\
\hline 28 & MPC & MINH PHÚ & No & Yes & Yes \\
\hline 29 & HUNGCA & Hùng Cá & No & Yes & No \\
\hline 30 & VTF & VTFEED & No & Yes & No \\
\hline 31 & HVG & HV GROUP & No & Yes & Yes \\
\hline 32 & $\mathrm{APT}$ & APT Co. & No & Yes & No \\
\hline
\end{tabular}




\section{Appendix B}

Table A2. Profile of respondent companies for interviews.

\begin{tabular}{|c|c|c|c|c|c|}
\hline Firm & Job Title & $\begin{array}{l}\text { No. of } \\
\text { Employees }\end{array}$ & Firm Age & $\begin{array}{l}\text { No. of Countries } \\
\text { Export }\end{array}$ & $\begin{array}{l}\text { Year Start } \\
\text { Green Practice }\end{array}$ \\
\hline 1 & $\begin{array}{l}\text { 1A-Export Manager } \\
\text { 1B-General Manager }\end{array}$ & 650 & 25 & 50 & 2007 \\
\hline 2 & $\begin{array}{l}\text { 2A-Export Manager } \\
\text { 2B-General Manager }\end{array}$ & 560 & 24 & 50 & 2008 \\
\hline 3 & 3A-Export Manager & 480 & 22 & 43 & 2010 \\
\hline 4 & $\begin{array}{l}\text { 4A-Export Manager } \\
4 \mathrm{~B}-\text {-HMR Manager }\end{array}$ & 120 & 15 & 30 & 2015 \\
\hline 5 & 5A-General Manager & 162 & 18 & 30 & 2007 \\
\hline 6 & $\begin{array}{l}\text { 6A-Export Manager } \\
\text { 6B-General Manager }\end{array}$ & 580 & 25 & 50 & 2005 \\
\hline 7 & 7A-Export Manager & 120 & 10 & 12 & 2017 \\
\hline 8 & $\begin{array}{l}\text { 8A-Export Manager } \\
\text { 8B-Operation Manager }\end{array}$ & 130 & 10 & 14 & 2016 \\
\hline 9 & $\begin{array}{l}\text { 9A-Export Manager } \\
\text { 9B-General Manager }\end{array}$ & 300 & 15 & 20 & 2012 \\
\hline 10 & $\begin{array}{l}\text { 10A-Marketing Manager } \\
\text { 10B-General Manager }\end{array}$ & 500 & 27 & 45 & 2008 \\
\hline 11 & 11A-Export Manager & 160 & 14 & 13 & 2016 \\
\hline 12 & 12A-HMR Manager & 155 & 12 & 12 & 2017 \\
\hline 13 & $\begin{array}{l}\text { 13A-Export Manager } \\
\text { 13B-General Manager }\end{array}$ & 275 & 22 & 32 & 2009 \\
\hline 14 & 14A-Export Manager & 100 & 12 & 8 & 2017 \\
\hline 15 & $\begin{array}{l}\text { 15A-HMR Manager } \\
\text { 15B-Marketing Manager }\end{array}$ & 90 & 12 & 6 & 2017 \\
\hline 16 & 16A-Marketing Manager & 90 & 10 & 6 & 2018 \\
\hline 17 & 17A-General Manager & 80 & 8 & 5 & 2018 \\
\hline 18 & $\begin{array}{l}\text { 18A-Export Manager } \\
\text { 18B-Operation Manager }\end{array}$ & 450 & 18 & 22 & 2009 \\
\hline 19 & $\begin{array}{l}\text { 19A-Chairman of the Board } \\
\text { 19B-General Manager }\end{array}$ & 500 & 26 & 40 & 2007 \\
\hline 20 & $20 \mathrm{~A}$ - Chairman of the Board & 120 & 7 & 4 & 2018 \\
\hline 21 & $\begin{array}{l}\text { 21A-Marketing Manager } \\
\text { 21B-Operation Manager }\end{array}$ & 90 & 10 & 5 & 2018 \\
\hline 22 & $22 \mathrm{~A}-$ Chairman of the Board & 80 & 9 & 4 & 2017 \\
\hline 23 & $\begin{array}{l}\text { 23A-Export Manager } \\
\text { 23B-General Manager }\end{array}$ & 88 & 8 & 6 & 2016 \\
\hline 24 & $24 \mathrm{~A}$ - Chairman of the Board & 120 & 9 & 7 & 2016 \\
\hline 25 & $\begin{array}{l}\text { 25A-General Manager } \\
\text { 25B-Operation Manager }\end{array}$ & 265 & 14 & 22 & 2011 \\
\hline 26 & $\begin{array}{l}\text { 26A-General Manager } \\
\text { 26B-Marketing Manager }\end{array}$ & 330 & 19 & 34 & 2008 \\
\hline 27 & $\begin{array}{l}\text { 27A-Export Manager } \\
\text { 27B_-HMR Manager }\end{array}$ & 550 & 23 & 38 & 2008 \\
\hline 28 & 28A-General Manager & 82 & 8 & 6 & 2016 \\
\hline
\end{tabular}

\section{References}

1. FAO. The State of World Fisheries and Aquaculture 2018-Meeting the Sustainable Development Goals; Food and Agriculture Organization of the United Nations: Rome, Italy, 2018; ISBN 9789251305621.

2. Banerjee, S.B. Managerial perceptions of corporate environmentalism: Interpretations from industry and strategic implications for organizations. J. Manag. Stud. 2001, 38, 489-513. [CrossRef] 
3. Leonidou, L.C.; Katsikeas, C.S.; Fotiadis, T.A.; Christodoulides, P. Antecedents and consequences of an eco-friendly export marketing strategy: The moderating role of foreign public concern and competitive intensity. J. Int. Mark. 2013, 21, 22-46. [CrossRef]

4. Katsikeas, C.S.; Leonidou, C.N.; Zeriti, A. Eco-friendly product development strategy: Antecedents, outcomes, and contingent effects. J. Acad. Mark. Sci. 2016, 44, 660-684. [CrossRef]

5. Pijl, W.v.d.; Duijn, A.P.v.; Beukers, R. The Vietnamese Seafood Sector: A Value Chain Analysis; CBI-Ministry of Foreign Affairs of the Netherlands: The Hague, The Netherlands, 2012.

6. Biçakcioğlu, N. Green business strategies of exporting manufacturing firms: Antecedents, practices, and outcomes. J. Glob. Mark. 2018, 31, 246-269. [CrossRef]

7. Aragón-Correa, J.A.; Rubio-López, A.E. Proactive corporate environmental strategies: Myths and misunderstandings. Long Range Plan. 2007, 40, 357-381. [CrossRef]

8. Leonidou, L.C.; Fotiadis, T.A.; Christodoulides, P.; Spyropoulou, S.; Katsikeas, C.S. Environmentally friendly export business strategy: Its determinants and effects on competitive advantage and performance. Int. Bus. Rev. 2015, 24, 798-811. [CrossRef]

9. Gupta, H.; Barua, M.K. A framework to overcome barriers to green innovation in smes using bwm and fuzzy topsis. Sci. Total Environ. 2018, 633, 122-139. [CrossRef] [PubMed]

10. González-Benito, J.; González-Benito, Ó. A review of determinant factors of environmental proactivity. Bus. Strategy Environ. 2006, 15, 87-102. [CrossRef]

11. Fan, Z.; $\mathrm{Wu}, \mathrm{D}$; $\mathrm{Wu}, \mathrm{X}$. Proactive and reactive strategic flexibility in coping with environmental change in innovation. Asian J. Technol. Innov. 2013, 21, 187-201. [CrossRef]

12. Lee, S.Y.; Rhee, S.K. The change in corporate environmental strategies: A longitudinal empirical study. Manag. Decis. 2007, 45, 196-216. [CrossRef]

13. Smith, G. Deliberative democracy and the public sphere. Philos. Soc. Crit. 2003, 27, 21-39.

14. Zeriti, A.; Robson, M.J.; Spyropoulou, S.; Leonidou, C.N. Sustainable export marketing strategy fit and performance. J. Int. Mark. 2014, 22, 44-66. [CrossRef]

15. Wright, M.; Filatotchev, I.; Hoskisson, R.E.; Peng, M. Strategic research in emerging markets: Challenging the conventional wisdom. J. Manag. Stud. 2005, 42, 1-33. [CrossRef]

16. Saunders, M.; Lewis, P.; Thornhill, A. Research Methods for Business Students; Pearson: Harlow, UK, 2012.

17. Anh, P.T.; Bush, S.R.; Mol, A.P.J.; Kroeze, C. The multi-level environmental governance of vietnamese aquaculture: Global certification, national standards, local cooperatives. J. Environ. Policy Plan. 2011, 13, 373-397. [CrossRef]

18. VASEP. Report on Seafood Industry 2018; Vietnam Association of Seafood Exporters and Producers: Ho Chi Minh city, Vietnam, 2018; pp. 1-39.

19. Das, A.K.; Biswas, S.R.; Abdul Kader Jilani, M.M.; Uddin, M.A.; Das, A.K.; Biswas, S.R.; Abdul Kader Jilani, M.M.; Uddin, M.A. Corporate environmental strategy and voluntary environmental behavior-mediating effect of psychological green climate. Sustainability 2019, 11, 3123. [CrossRef]

20. Buysse, K.; Verbeke, A. Proactive environmental strategies: A stakeholder management perspective. Strateg. Manag. J. 2003, 24, 453-470. [CrossRef]

21. Racela, O.C.; Chaikittisilpa, C.; Thoumrungroje, A. Market orientation, international business relationships and perceived export performance. Int. Mark. Rev. 2007, 24, 144-163. [CrossRef]

22. Fraj-Andrés, E.; Martínez-Salinas, E.; Matute-Vallejo, J. Factors affecting corporate environmental strategy in spanish industrial firms. Bus. Strategy Environ. 2009, 18, 500-514. [CrossRef]

23. Leonidou, L.C.; Christodoulides, P.; Kyrgidou, L.P.; Palihawadana, D. Internal drivers and performance consequences of small firm green business strategy: The moderating role of external forces. J. Bus. Ethics 2017, 140, 585-606. [CrossRef]

24. Leonidou, L.C.; Palihawadana, D.; Theodosiou, M. National export-promotion programs as drivers of organizational resources and capabilities: Effects on strategy, competitive advantage, and performance. J. Int. Mark. 2011, 19, 1-29. [CrossRef]

25. Leonidou, L.C.; Samiee, S.; Aykol, B.; Talias, M.A. Antecedents and outcomes of exporter-importer relationship quality: Synthesis, meta-analysis, and directions for further research. J. Int. Mark. 2014, 22, 21-46. [CrossRef]

26. Oliver, C. Strategic responses to institutional processes. Acad. Manag. Rev. 1991, 16, 145-179. [CrossRef]

27. Aragón-Correa, J. Strategic proactivity and firm approach to the natural environment. Acad. Manag. J. 1998, 41, 556-567. [CrossRef] 
28. Hart, S.L.; Ahuja, G. Does it pay to be green? An empirical examination of the relationship between emission reduction and firm performance. Bus. Strategy Environ. 1996, 5, 30-37. [CrossRef]

29. Russo, M.V.; Fouts, P.A. A Resource-based perspective on corporate environmental performance and profitability. Acad. Manag. J. 1997, 40, 534-559.

30. de Bakker, F.; Nijhof, A. Responsible chain management: A capability assessment framework. Bus. Strategy Environ. 2002, 11, 63-75. [CrossRef]

31. Sharma, S. Managerial interpretations and organizational context as predictors of corporate choice of environmental strategy. Artic. Acad. Manag. J. 2000, 43, 681-697.

32. Sharma, S.; Vredenburg, H. Proactive corporate environmental strategy and the development of competitively valuable organizational capabilities. Strateg. Manag. J. 2005, 19, 729-753. [CrossRef]

33. Kim, S. Proactive versus Reactive Corporate Environmental Practices and Environmental Performance. Sustainability 2018, 10, 97. [CrossRef]

34. Roome, N. Developing environmental management strategies. Bus. Strategy Environ. 1992, 1, 11-24. [CrossRef]

35. Chen, Y.S.; Chang, C.H.; Wu, F.S. Origins of green innovations: The differences between proactive and reactive green innovations. Manag. Decis. 2012, 50, 368-398. [CrossRef]

36. Ryszko, A. Proactive Environmental Strategy, Technological Eco-Innovation and Firm Performance-Case of Poland. Sustainability 2016, 8, 156. [CrossRef]

37. Jiang, Y.; Xue, X.; Xue, W. Proactive Corporate Environmental Responsibility and Financial Performance: Evidence from Chinese Energy Enterprises. Sustainability 2018, 10, 694. [CrossRef]

38. Bansal, P. Evolving sustainably: A longitudinal study of corporate sustainable development. Strateg. Manag. J. 2005, 26, 197-218. [CrossRef]

39. Delmas, M.; Toffel, M.W. Stakeholders and environmental management practices: An institutional framework. Bus. Strategy Environ. 2004, 13, 209-222. [CrossRef]

40. Amit, R.; Schoemaker, P.J.H. Strategic assets and organizational rent. Strateg. Manag. J. 1993, 14, 33-46. [CrossRef]

41. Barney, J. Firm resources and sustained competitive advantage. J. Manag. 1991, 17, 99-120. [CrossRef]

42. Bharadwaj, S.G.; Varadarajan, P.R.; Fahy, J. Sustainable competitive advantage in service industries: A conceptual model and research propositions. J. Mark. 1993, 57, 83-99. [CrossRef]

43. Shrivastava, P. The role of corporations in achieving ecological sustainability. Acad. Manag. Rev. 1995, 20, 936-960. [CrossRef]

44. Wernerfelt, B. A resource-based view of the firm. Strateg. Manag. J. 1984, 5, 171-180. [CrossRef]

45. Grant, R.M. Porter's 'competitive advantage of nations': An assessment. Strateg. Manag. J. 1991, 12, 535-548. [CrossRef]

46. Hall, R. A framework linking intangible resources and capabiliites to sustainable competitive advantage. Strateg. Manag. J. 1993, 14, 607-618. [CrossRef]

47. Poisson-de Haro, S.; Bitektine, A. Global sustainability pressures and strategic choice: The role of firms' structures and non-market capabilities in selection and implementation of sustainability initiatives. J. World Bus. 2015, 50, 326-341. [CrossRef]

48. Aguilera-Caracuel, J.; Hurtado-Torres, N.E.; Aragón-Correa, J.A. Does international experience help firms to be green? A knowledge-based view of how international experience and organisational learning influence proactive environmental strategies. Int. Bus. Rev. 2012, 21, 847-861. [CrossRef]

49. Marshall, R.S.; Akoorie, M.E.M.; Hamann, R.; Sinha, P. Environmental practices in the wine industry: An empirical application of the theory of reasoned action and stakeholder theory in the united states and new zealand. J. World Bus. 2010, 45, 405-414. [CrossRef]

50. Pinkse, J.; Kuss, M.J.; Hoffmann, V.H. On the implementation of a 'global' environmental strategy: The role of absorptive capacity. Int. Bus. Rev. 2010, 19, 160-177. [CrossRef]

51. Bowen, F.E. Organizational slack and corporate greening: Broadening the debate. Br. J. Manag. 2002, 13, 305-316. [CrossRef]

52. Quazi, H.A.; Khoo, Y.K.; Tan, C.M.; Wong, P.S. Motivation for iso 14000 certification: Development of a predictive model. Omega 2001, 29, 525-542. [CrossRef]

53. Fernández, E.; Junquera, B.; Ordiz, M. Organizational culture and human resources in the environmental issue: A review of the literature. Int. J. Hum. Resour. Manag. 2003, 14, 634-656. [CrossRef] 
54. Teece, D.J.; Gary, P.; Shuen, A. Dynamic capabilites and strategic management. Strateg. Manag. J. 1997, 18, 509-533. [CrossRef]

55. Marcus, A.; Geffen, D. The dialectics of competency acquisition: Pollution prevention in electric generation. Strateg. Manag. J. 1998, 19, 1145-1168. [CrossRef]

56. Khattak, A.; Stringer, C.; Benson-Rea, M.; Haworth, N. Environmental upgrading of apparel firms in global value chains: Evidence from Sri Lanka. Compet. Chang. 2015, 19, 317-335. [CrossRef]

57. Vachon, S.; Klassen, R.D. Environmental management and manufacturing performance: The role of collaboration in the supply chain. Int. J. Prod. Econ. 2008, 111, 299-315. [CrossRef]

58. Lichtenthaler, U. Absorptive capacity, environmental turbulence, and the complementarity of organizational learning processes. Acad. Manag. J. 2009, 52, 822-846. [CrossRef]

59. Porter, M.E. The Competitive Advantage of Nations; The Free Press: New York, NY, USA, 1990.

60. Busch, L.; Bain, C. New! Improved? The transformation of the global agrifood system. Rural Sociol. 2004, 69, 321-346. [CrossRef]

61. Raynolds, L.T. The globalization of organic agro-food networks. World Dev. 2004, 32, 725-743. [CrossRef]

62. Jaworski, B.J.; Kohli, A.K. Market orientation: Antecedents and consequences. J. Mark. 1993, 57, 53-70. [CrossRef]

63. Lin, L.-H.; Ho, Y.-L. Institutional pressures and environmental performance in the global automotive industry: The mediating role of organizational ambidexterity. Long Range Plan. 2016, 49, 764-775. [CrossRef]

64. Tran, N.; Bailey, C.; Wilson, N.; Phillips, M. Governance of global value chains in response to food safety and certification standards: The case of shrimp from Vietnam. World Dev. 2013, 45, 325-336. [CrossRef]

65. Ministry of Finance. Circular no. 155/2015/tt-btc. Available online: https://aasc.com.vn/web/index.php/en/ tin-tuc/quy-dinh-moi/item/804-circular-no-155-2015-tt-btc (accessed on 19 May 2019).

66. Dean, T.J.; McMullen, J.S. Toward a theory of sustainable entrepreneurship: Reducing environmental degradation through entrepreneurial action. J. Bus. Ventur. 2007, 22, 50-76. [CrossRef]

67. Walls, J.L.; Phan, P.H.; Berrone, P. Measuring environmental strategy: Construct development, reliability, and validity. Bus. Soc. 2011, 50, 71-115. [CrossRef]

68. Day, G.S. The capabilities of market-driven organizations. J. Mark. 1994, 58, 37. [CrossRef]

69. Helfat, C.E.; Peteraf, M.A. The dynamic resource-based view: Capability lifecycles. Strateg. Manag. J. 2003, 24, 997-1010. [CrossRef]

70. Zheng, S.; Zhang, W.; Du, J. Knowledge-based dynamic capabilities and innovation in networked environments. J. Knowl. Manag. 2011, 15, 1035-1051. [CrossRef]

71. Mcewin, A.; Mcnally, R. Organic Shrimp Certification and Carbon Financing: An Assessment for the Mangroves and Markets Project in Ca Mau Province, Vietnam. Available online: http://www.snv.org/public/cms/sites/ default/files/explore/download/140007_mangrove_shrimp_report_single-lr.pdf (accessed on 8 May 2019).

72. Jacquet, J.L.; Pauly, D. The rise of seafood awareness campaigns in an era of collapsing fisheries. Mar. Policy 2007, 31, 308-313. [CrossRef]

73. Iles, A. Making the seafood industry more sustainable: Creating production chain transparency and accountability. J. Clean. Prod. 2007, 15, 577-589. [CrossRef]

74. Nguyen, T.V.A.; Wilson, N.L.W. Effects of Food Safety Standards on Seefood Exports to US, EU and Japan. In Proceedings of the Southern Agricultural Economics Association Annual Meeting, Atlanta, GA, USA, 31 January-3 February 2009; pp. 1-22.

75. Blomquist, J.; Bartolino, V.; Waldo, S. Price premiums for providing eco-labelled seafood: Evidence from msc-certified cod in Sweden. J. Agric. Econ. 2015, 66, 690-704. [CrossRef]

76. Galati, A.; Pastor, L.M.; Crescimanno, M.; Giaimo, R.; Giacomarra, M. Sustainable European fishery and the friend of the sea scheme: Tools to achieve sustainable development in the fishery sector. Int. J. Glob. Small Bus. 2015, 7, 247. [CrossRef]

77. Twining, P.; Heller, R.S.; Nussbaum, M.; Tsai, C.C. Some guidance on conducting and reporting qualitative studies. Comput. Educ. 2017, 106, A1-A9. [CrossRef]

(C) 2019 by the authors. Licensee MDPI, Basel, Switzerland. This article is an open access article distributed under the terms and conditions of the Creative Commons Attribution (CC BY) license (http://creativecommons.org/licenses/by/4.0/). 